\title{
LITTLE FEATURES OF FOREIGN EXPERIENCE IN EDUCATION OF CHILDREN IN PRESCHOOL EDUCATIONAL INSTITUTIONS
}

\author{
Marhabo Khudoykulovna Kilichova
}

Teacher of The Department Of Preschool Education Methods, Faculty Of Preschool Education, Jizzakh State Pedagogical Institute, Uzbekistan

\section{ABSTRACT}

This article discusses the specifics of foreign experience in raising children in preschool education. In Japan, Korea, the United States, Germany, the United Kingdom, and Russia, the preschool education system has its own peculiarities of child rearing. There are also specific recommendations on the correct choice of educational tools in preschool education. It was also noted that an analytical approach is needed in the use of best practices abroad. The specifics of the entire national education system are also highlighted, and the main tasks of pre-school education and upbringing in Uzbekistan are outlined.

KEYWORDS:- Preschool education, educator, foreign experience, developed countries, educational tool, Uzbekistan, Japan, Korea, USA, Germany, UK, Russia, concept, national programs, child, person, citizen, best practices, national moving games, technocratic, information, modern pedagogical technologies, family, mother, duty, position.

\section{INTRODUCTION}

Uzbekistan is making rapid progress in education reform. Because the purpose of the large-scale reforms is being carried out today is to bring up a harmoniously developed generation that will ensure the future development of Uzbekistan. In this regard, the Eastern thinker Abu Nasr Farobi said that the main task of education is to bring up a mature person for the existing society".?p.17, 1 ?

Indeed, the main criterion of the ongoing reforms in the field of education is aimed at educating a generation that is physically and mentally healthy, with intellectual potential. Preschool education was the primary link in this system of education. In recent years, laws and decisions aimed at reforming and developing the system of preschool education in Uzbekistan have been adopted and put into practice. Resolution of the President of the Republic of Uzbekistan № PQ 4312 of May 8, 2019 "On approval of the Concept of development of preschool education in the Republic of Uzbekistan until 2030" ?20-for example, this concept the development of educational services, in a word, encompasses the target tasks of the development of the preschool 
education system and defines the priorities and stages of the process.

Further development of the preschool education system also requires the organization of foreign experience, analysis of their achievements and the implementation of best practices of developed countries without abandoning national education.

Accordingly, the best practices of several foreign developed countries were analyzed.

\section{Methods}

In Japan, children are sent to school when they reach the age of six. Until then, the children will be educated in kindergarten. During kindergarten, teachers teach children to read simple calculations, as well as the "hiragana" and "katakana" alphabets, as it decreases over time.

In Japan, pre-school education usually begins in the family. For Japanese women, motherhood comes first. Many Japanese women say that raising children is the goal of their lives. In Japan, $59.9 \%$ of preschools are private and $40.8 \%$ are public.

In Japanese kindergartens, a child's skills of dealing with life's problems are gradually formed from an early age, using unique parenting techniques.

For example:

At the age of 1 year, the child is taught to feel less confident;

At the age of 2 he is trained in manual labor through applied arts;

At the age of 3, children develop a sense of duty;

At the age of 4 he is taught to distinguish between good and evil;

At the age of 5, the child develops leadership qualities, teaches them independence and develops skills in making plans and implementing them.

In Japan, boys and girls are raised differently. Boy is seen as the future support of the family and is taught to overcome difficulties from childhood. Girls are also prepared for housework from childhood.

In Japanese kindergartens, children are divided into small groups of 8 people - "khans". These children are given fewer jobs in kindergarten, and they choose fewer "khans". In this way, they are taught to work in a team from an early age. In each foster group in this group, skills to form a small position are formed.

The Japanese also pay a lot of attention to environmental education. They are building an entire island from compressed waste today. Of course, children also contribute to this. ?p.669, 8?

Preschool education is provided in preschools in the United States, including public and private nurseries, kindergartens, and preschools. The state actively supports the educational mission of pre-school education institutions and provides financial assistance for the pre-school education and preparation of children for school.

Many 5-year-old American children attend preparatory classes in kindergarten. In this class, children prepare for fluency in elementary school, that is, they gradually jump from month to month to master reading, writing, and other necessary skills. Sixty percent of five-year-olds attend public preschools, but many parents prefer private preschools.

In Korea, kindergartens are not part of the general education program, with parents enrolling children in private institutions. Children from 3 to 5 years old are admitted to the kindergarten. Children over the age of six usually go to school. Since the 1980s, the number of children attending kindergartens and preschools has increased dramatically: there 
were 66,433 children attending 901 institutions in 1980, compared to 7,792 in 1987, bringing the number of children enrolled to 397,020. The number of educators and teachers has also increased, most of them women.

Korean kindergartens are divided into the following types: primary; average; high. The South Korean pre-school education system is mainly focused on teaching a child basic allround developmental skills. From the age of three, children learn to read and write in Korean and English. From this age, children learn the secrets of mathematics. Koreans pay special attention to the physical health and vigor of children, as well as the lack of music lessons. From kindergarten onwards, children are given a very large amount of homework, and in addition to translating individual words and sentences in English lessons, children are organized to fluently and simply adjust their little thoughts and opinions in English.

In Korea, children over the age of 6 are accepted for primary education until March 1 of the school year. However, 5-year-olds are also eligible to enter the school, which requires the permission of the person in charge of the school.

The main task of the kindergarten is to create conditions for the full development of families. Kindergartens mainly teach music, drawing and arithmetic. In Korean kindergartens, great emphasis is placed on the formation of independence in children. ?Pp.47-48, 4 ?

In the UK, education is usually focused on the child, not the subject or teacher being organized. Such an approach is based on the history of English education, the development of which was influenced by Russo, Frebel, Montessori. They believed that it was necessary to develop the individuality of the child and protect his independence. The main objectives of preschool education are: to meet the needs and interests of each child, to respect the difference between children. It is assumed that the child has an inner desire to flow, is curious and energetic by nature. Training should be conducted during the month the child is offered. The main task of the teacher is to support the moon, not by teaching the child, to provide him with various materials for

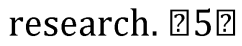

German law provides for the right to free preschool education. Children can be taken to kindergarten from 4 months. Many Germans exercise this right. In Germany, grandparents who are members of the older generation have no concept of the obligation to retire and look after their grandchildren after they are born. That is why parents are forced to send their children to kindergartens and nurseries.

The various forms and types of German preschools (MTCs) are as follows:

1. Waldkindergarten (forest from the German word Wald, Kindergarten). The idea of creating such kindergartens began in Scandinavia. Often such gardens are located in the woods. Kids are always outdoors, organizing trees and other plants, making different things from natural materials. Children are taught to love and care for nature.

2. Bauernhofkindergarten (from the German word Bauernhof, a farmer's yard, a castle; Kindergarten). Such gardens will be located on dehkan farms, farms or nearby lands. The children help the farmers to feed the cattle, grow vegetables and fruits in the fields and orchards until they are strong enough.

3. Reggio-Kindergarten. The concept of creating such kindergartens originated in the Italian city of Reggio Emilio, and the name is derived from it. Such a preschool is reminiscent of a large room (hall) in the middle, reminiscent of a market (fair) area, and a building leading from it to different "neighborhoods" of the town in small rooms. The environment in which children are 
housed in this type of kindergarten is called the primary caregiver. Every morning, the children meet with the tutor in a large room to discuss the day's plan, and then disperse to the rooms. One room will be converted into a room for construction and assembly of various constructors. Here children can play with cubes, collect constructors. There is also a drawing room, where paint and paper are usually hung on the walls. The children are dressed in special clothes and they can paint the walls, the floor, each other wherever they want. There are also craft, music and other rooms. In such kindergartens, educators help children only to take up space around them.

4. Freinet-Kindergarten. This direction of preschool pedagogy derives its name from the Italian family couple, who developed a unique approach to the upbringing of children. The main principle of this direction is the complete freedom and independence of the child. In Fryneth Kindergarten, children decide for themselves what to do, how to play the moon, what to do, when to eat and sleep. In the socalled "Children's Conference", children set their own rules of conduct within the MTC. In such kindergartens, great emphasis is placed on creativity, role-playing games, experiments, excursions to nature or the city's enterprises and organizations.

5. Integrated kindergartens. In this type of MTCs, physically and mentally ill children are brought up together with healthy children. Such an environment is seen as a great opportunity for ordinary children to organize resilience, tolerance and respect. Children with disabilities are not isolated from society, they are less likely to communicate and interact with their peers. The large number of such kindergartens and schools in Germany creates favorable conditions for people with disabilities to live, study and perform.
6. International kindergartens. Such MTCs are designed for immigrants and are often organized by a small number of immigrants for their children. There are many Turkish-German, Jewish, Russian-German kindergartens in Germany. The concept of these institutions is based on the principle of bilingualism 1 . That is, there will always be a German-speaking tutor in the groups as well as a native-language tutor with the children. In doing so, children learn both their parents' language and German.

Russian-German kindergartens often use programs by Russian authors. It also includes classes dedicated to many holidays in Russia, such as Maslenitsa, March 8, and New Year. [6]

The state policy of the Russian Federation in the field of education is based on the ideas of humanism and democracy, which are reflected in the Constitution and the Law "On Education". These documents explicitly state that education is a process of education and upbringing aimed at the interests of the state, society and the individual.

The structure of Russian education consists of curricula and state standards and directions of different levels, as well as governing bodies of institutions outside the education system and subject to the education system. Preschool education is the first stage of the education system in the Russian Federation. The idea of providing educational opportunities for even the youngest children appeared in 1918 after the creation of the "Regulations on the Unified School of Labor." From the date of adoption of the statute, every child is guaranteed the right to discharge from birth.

The pre-school education system in Russia is constantly evolving, constantly updating, changing its appearance and improving.

The first teachers for a child are his parents. They must raise children physically, 
intellectually, and morally from infancy. The activities of pre-school educational institutions (PRE) are aimed at helping families to acquire knowledge and at the next stage of education.

Russia's preschool education system is based on the Concept of Modernization of the Educational Process. This concept emphasizes the importance of ensuring the quality of education. This document is based on the Law on Education, the Constitution of the Russian Federation, the Model Regulations on MTC and other decisions of the Ministry of Education. This Concept emphasizes the need to update the content of education based on the useful experience of individual organizations. [7]

\section{Conclusion}

In general, preschool education organizations are required to choose the right method of education, to conduct education and upbringing in an integrated manner. However, in the Eastern countries, education is a priority in the educational process. Because in the formation of personality we have the main emphasis on upbringing. The reason is that moral education plays an important role in the development of the individual. At the same time, in connection with civic education, a person develops such qualities as belonging to the state, patriotism, responsibility, having a life position. This method of upbringing also plays an important role in the upbringing of the nation. The nation's understanding and respect for values, its unity around noble ideas and ideologies, will inevitably depend on their upbringing from a young age.

In conclusion, we can say that today a new approach to the educational process in preschool education and upbringing is required. At the same time, it is necessary to introduce the best practices of developed foreign countries into the national and modern education system through the organization, analysis and filtering. For example, in the field of child rearing, Japanese educators have found a way to save the young Japanese generation in Uzbekistan. Today, some of our people are collecting and taking away the moving moons that they don't play because they aren't modern, and passing them on to their super-modern children.

The reason is that modern children's games have become too technocratic. They lack human spirit, charm, pleasure and emotion. This means that we must make effective use of our national means of education. Along with didactic games developed on the basis of modern pedagogical technologies, we must not forget about the national games inherited from our ancestors. Because these months have such unique features, through which positive qualities in children, such as intimacy, cohesiveness, willpower, are formed through certain actions. Of course, this requires taking into account the age of the child. [p. 634, 9]

Therefore, in choosing the means of education in preschool education, it is necessary to adapt the best practices of foreign countries without giving up the moral, physical, labor education of a national character. There will be healthy competition among preschool education institutions. This process, in turn, will serve to bring up a healthy, educated and intellectually gifted generation for the new Uzbekistan, the third Renaissance.

\section{ReFERENCES}

1. Niyazov G., Ahmedov K., Tadjibayev K. Spiritual and moral views of Eastern scholars and enlightened writers on the upbringing of a harmoniously developed generation. $\mathrm{T}$.: Uzbekistan, 2010, p.17.

2. Resolution of the President of the Republic of Uzbekistan. № PP-4312 "On approval of the Concept of development of the system of 
CURRENT RESEARCH JOURNAL OF PEDAGOGICS 2(10): 241-246

October 2021 DOI: https://doi.org/10.37547/pedagogics-crjp-02-10-43

ISSN 2767-3278

(C)2021 Master Journals

Crossref do) 81 Google

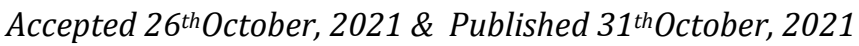

preschool education of the Republic of Uzbekistan until 2030". May 8, 2019. https://lex.uz.

3. https://capitalsc.ru/yaponskiy-alfavit/

4. Fazilova D.H Educational-methodical complex from the module on the use of foreign experience and innovative technologies. Jizzakh, 2021, pp. 47-48.

5. http://sdojournal.ru/journalnumbers/anglijskajasistema-do.html

6. http://razvivash-ka.ru/sistemadoshkolnogo-obrazovania-v-germanii/

7. https://edunews.ru/educationabroad/sistemaobrazovaniya/doshkolnoe.html

8. Qilichova M.Kh, Hamrayeva E. Issues of formation of ecological knowledge and culture in preschool educational institutions. Asian Journal of Multidimensional Research (AJMR). Vol 10, Issue 4, April 2021, P.669. Impact Factor: SJIF-2021 = 7,699.

9. Qilichova M.X. Methods of formation of creative thinking skills in pupils of preschool educational institutions. Proceedings of the International Scientific and Practical Online Conference. "On Innovative and Integrative Approaches in the Education System of the XXI Century". Jizzakh. 2021, p. 634. 